\title{
Mengabadikan Makna Enjoyment pada Sentra Kuliner dan Oleh-Oleh
}

\author{
I Made Denny Krishnantara Surya, dan I Gusti Ngurah Antaryama \\ Departemen Arsitektur, Fakultas Arsitektur, Desain dan Perencanaan, Institut Teknologi Sepuluh Nopember (ITS) \\ e-mail: antaryama@arch.its.ac.id
}

\begin{abstract}
Abstrak-Penutupan aktivitas prostitusi di kawasan Putat Jaya pada tahun 2014 lalu memberi dampak pada kehidupan masyarakat sekitar. Dampak tersebut terjadi akibat hilangnya daya tarik dari kawasan ini sehingga membutuhkan daya tarik atau brand baru. Re-brand-ing dilakukan dengan menggunakan teori makna dalam arsitektur. Citra yang akan dibentuk untuk kawasan Putat Jaya merupakan penggeseran citra "pleasure" yang erat dengan kegiatan prostitusi menjadi citra atau makna "enjoyment" yang akan diabadikan pada sebuah objek desain. Objek desain ini merupakan respon terhadap kebutuhan, potensi, dan profesi masyarakat setempat, yaitu sentra kuliner dan oleholeh. Pada proses desain sentra kuliner dan oleh-oleh, digunakan metode naratif untuk menceritakan mengenai makna enjoyment dalam objek desain. Sentra kuliner dan oleh-oleh didesain agar bisa menstimulus indra visual dan kinestetik, sehingga bisa menimbulkan kedekatan (immediacy) terhadap objek desain dan memunculkan makna enjoyment. Eksplorasi indra visual dan kinestetik dipadukan sehingga terbentuk konsep permukaan dinamis. Narasi desain dikaitkan dengan konsep permukaan dinamis untuk ditransformasi menjadi sebuah sentra kuliner dan oleh-oleh yang mengabadikan makna enjoyment. Maknn enjoyment pada arsitektur ini akan hadir pada bentuk permukaannya yang bergelombang dan berlipat-lipat.
\end{abstract}

Kata Kunci - Enjoyment, Makna, Naratif, Permukaan Dinamis, Sentra Kuliner.

\section{PENDAHULUAN}

$\mathrm{P}$ ENUTUPAN lokalisasi Dolly pada tahun 2014 lalu menyebabkan penurunan kondisi ekonomi penduduk kawasan Putat Jaya, yang berprofesi sebagai pedagang, jasa binatu, jasa parkir, dan jasa-jasa lainnya. Hal ini terjadi karena pengunjung kawasan menurun drastis akibat hilangnya hiburan dan daya tarik kawasan Putat Jaya - lokalisasi Dolly. Kawasan ini membutuhkan daya tarik baru sehingga bisa menimbulkan citra (image) baru di kawasan Putat Jaya.

Putat Jaya harus diberikan brand atau citra (image) baru sehingga bisa memiliki identitas baru dan rebranding bisa dilakukan (gambar 2). Pemberian citra pada kawasan Putat Jaya dilakukan dengan cara menggeser citra pleasure yang erat kaitannya dengan kegiatan prostitusi. Hal ini dilakukan untuk mengubah makna negatif dari citra lama kawasan Putat Jaya, sehingga memiliki makna baru yang positif tanpa harus meninggalkan makna lama secara keseluruhan. Selain itu, makna baru akan tetap memiliki keterkaitan dengan konteks lokasi desain. Hasil dari penggeseran makna kemudian

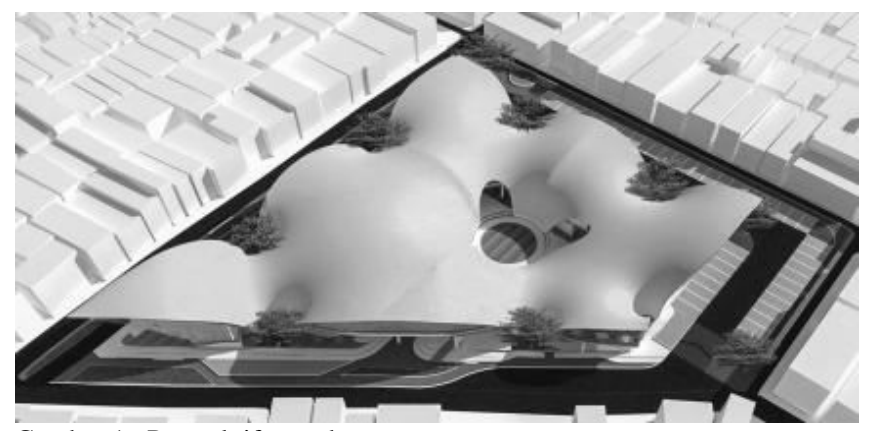

Gambar 1. Perspektif mata burung.

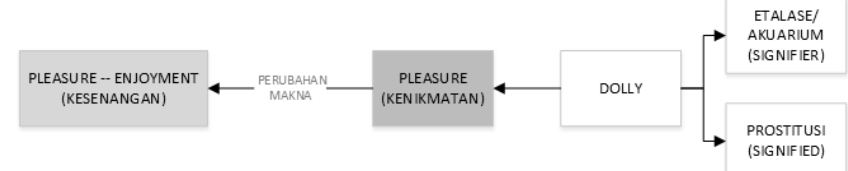

Gambar 2. Penggeseran makna pleasure menjadi enjoyment.

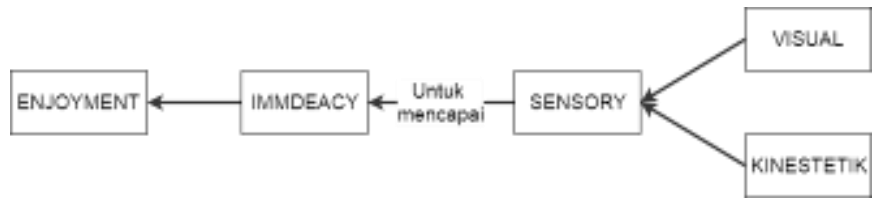

Gambar 3. Keterkaitan indra visual dan kinestetik terhadap makna enjoyment.

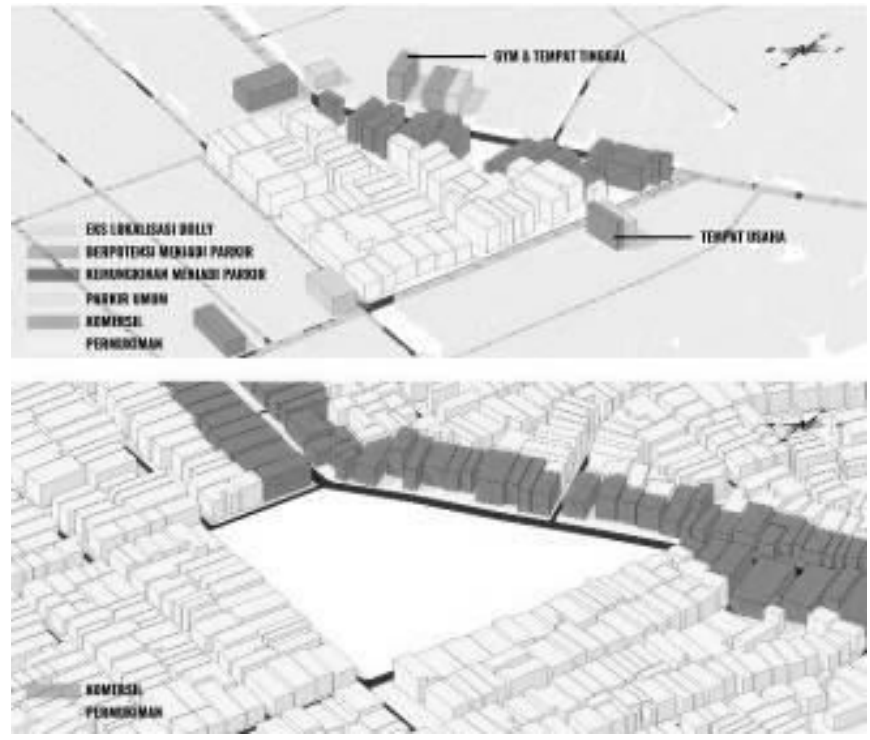

Gambar 4. Pemetaan kawasan sekitar lokasi tapak 
ditransformasi menjadi sebuah bangunan, yaitu sentra kuliner dan oleh-oleh sebagai respon terhadap kebutuhan, potensi, dan profesi masyarakat kawasan Putat Jaya.

Jika "komunikasi" dengan "promosi" disamakan dalam presentasi desain, sangat penting untuk diingat bahwa bahasa bisa berfungsi sebagai alat pemasaran yang sangat berpengaruh dan dapat digunakan untuk mendeskripsikan sebuah objek atau ide desain, serta bagaimana objek akan dilihat dan diinterpretasi oleh pengamat dan pengguna objek desain. Brand erat kaitannya dengan beberapa hal yaitu, metaphor, narrative, dan symbolism [1]. Dalam melakukan branding terhadap kawasan Putat Jaya, makna dalam arsitektur digunakan sebagai pendekatan atau sebagai cara memandang permasalahan desain.

\section{A. Pendekatan}

Makna sangat berkaitan dengan sistem tanda (semiologi). Kebanyakan objek arsitektural tidak berkomunikasi (dan tidak didesain untuk berkomunikasi), tapi hanya untuk menjalankan fungsinya saja. Hubungan kita dengan arsitektur menunjukkan bahwa kita sering kali merasakan arsitektur berkomunikasi dengan kita disaat kita mengenali fungsinya. Apa yang membuat kita berkomunikasi terhadap sesuatu adalah sebuah stimulus, sehingga menimbulkan respons tertentu. Dalam penggunaan suatu objek arsitektur (melewati, memasuki, naik, dll), tidak hanya sekedar fungsi yang ditimbulkan objek tersebut, melainkan makna yang berkaitan dengan objek tersebut. Hal ini yang membuat kita terbiasa dengan fungsi tertentu dari suatu objek [2].

Dalam semiotik, sign vehicle dapat ditafsirkan dengan cara denotasi (fungsi primer) dan konotasi (fungsi sekunder). Dalam sistem komunikasi, sign vehicle berkomunikasi dan secara konvensional mendenotasikan (eksplisit) - fungsinya. Selain menunjukkan fungsinya, objek arsitektural bisa berkonotasi atau memiliki arti tambahan (makna) terhadap ideologi tertentu mengenai fungsinya. Saat fungsi primer dan fungsi sekunder diinterpretasi oleh pengamat, fungsi primer dan fungsi sekunder bisa mengalami kehilangan makna yang dimaksud (tidak terkomunikasikan), pemulihan makna, atau diinterpretasi dengan makna lain (substitusi). Hal ini bergantung pada kultur, pengalaman, dan pengetahuan dari pengamat objek desain [2].

\section{B. Tapak}

Pada kasus ini dipilih satu lokasi desain dengan kriteria adalah lokasi tapak harus berada di tengah-tengah area paling terdampak, dengan tujuan agar pengunjung menyusuri dan dapat melihat area yang terdampak ketika menuju objek desain. Lokasi desain berada di Jl. Jarak, tepat di sebelah rumah bordil barbara yang bisa diakses dari dua jalan utama yaitu, Jl. Dukuh Kupang dan Jl. Banyu Urip (Gambar 3).

Dalam kesempatan ini, penulis berusaha menunjukkan penggeseran makna pleasure menjadi enjoyment dan ditransformasi menjadi sebuah sentra kuliner dan oleh-oleh.

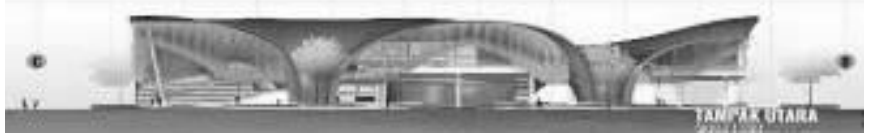

Gambar 5. Tampak utara bangunan, menunjukkan tampang bangunan yang meliuk seperti ombak.

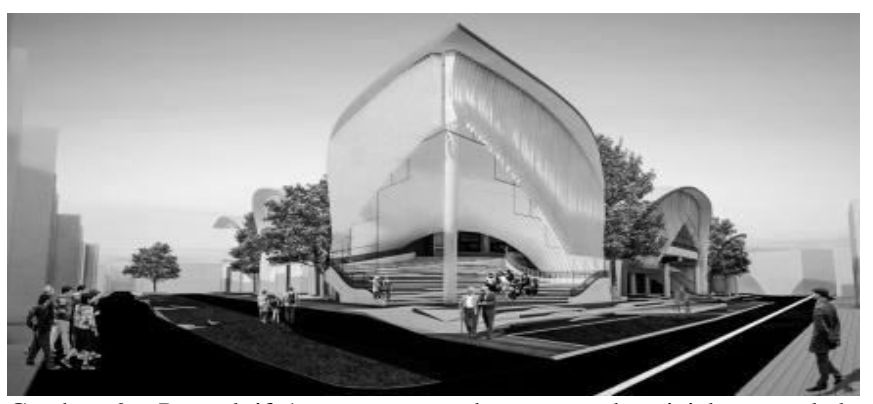

Gambar 6. Perspektif 1, area tangga dan ramp sebagai jalur masuk ke dalam bangunan.

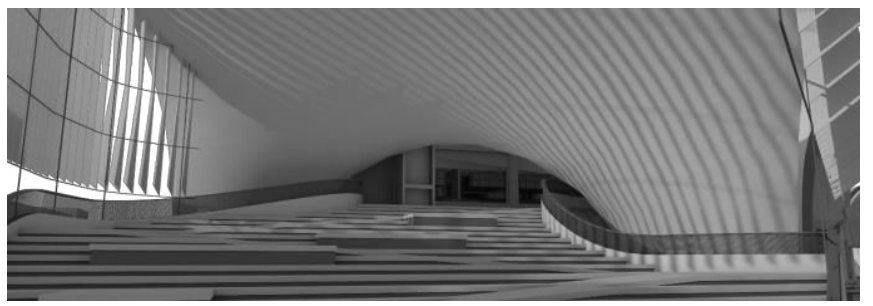

Gambar 7. Perspektif 2 interior, area tangga dan ramp sebagai sirkulasi masuk di dalam bangunan.

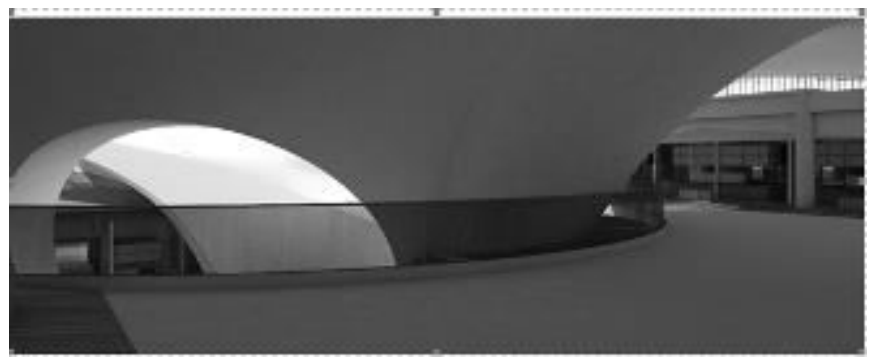

Gambar 8. Perspektif 3 interior, area makan tengah yang berhubungan dengan amphitheater sebagai orientasi bangunan.

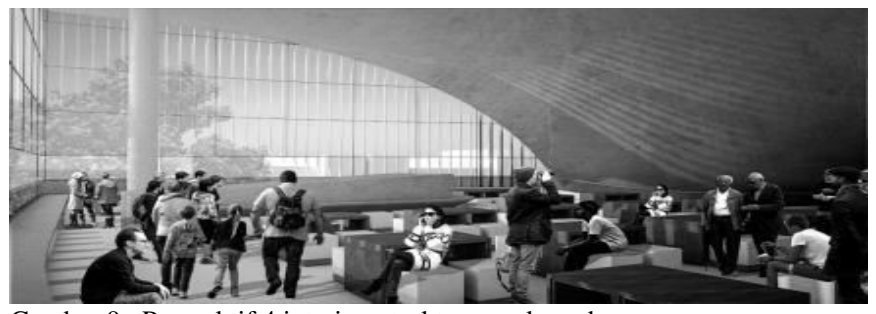

Gambar 9. Perspektif 4 interior, struktur cangkang bangunan.

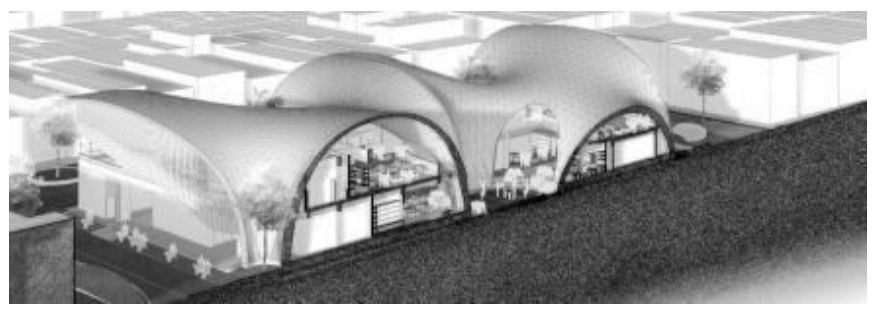

Gambar 10. Potongan 1, amphitheater sebagai orientasi dalam banguan. 


\section{METODE DESAIN}

\section{A. Indra Sebagai Eksplorasi Desain}

Menurut Henri Lefebvre, ruang yang menyenangkan adalah ruang yang dapat menciptakan momen. Ruang kontemplasi dan ruang mimpi (space of contemplation, the space of dream) merupakan ruang yang menyenangkan karena ruang-ruang ini bisa mengendalikan ambiguitas untuk mengarahkannya menuju kenikmatan (enjoyment) tertentu dan tidak pasti. Ketika arsitektur bisa menstimulus panca indra, maka ruang kontemplasi dan ruang mimpi akan muncul [3]. Seperti menikmati sebuah musik dan lukisan, musik dan lukisan bisa diinterpretasikan secara luas sehingga bisa memiliki makna yang luas. Warna, bentuk, dan garis dalam lukisan digunakan untuk menciptakan ambiguitas oleh sang pelukis. Ketika bentuk, garis, dan warna membentuk sesuatu secara simultan, dan menstimulus panca indra sehingga makna dari lukisan bisa diinterpretasi, dan lukisan bisa memiliki karakteristik tertentu.

Dalam mendesain sentra kuliner dan oleh-oleh dipilih eksplorasi indra visual dan kinestetik karena kedua indra ini utamanya berpengaruh terhadap program aktivitas dalam bangunan.

\section{B. Naratif}

Metode yang digunakan dalam mendesain sentra kuliner dan oleh-oleh adalah metode naratif. Metode ini juga digunakan untuk menceritakan mengenai makna yang dimaksud dalam objek desain dan konsep objek desain. Narasi desain dibuat secara sekuensial.

Naratif adalah kumpulan kejadian atau pengalaman yang saling terhubung. Naratif adalah suatu bentuk komunikasi dalam proses desain. Naratif juga merupakan cara komunikasi yang mendorong pengamat untuk memahami desain sesuai dengan alur [4]. Naratif juga berkaitan dengan transformasi mengungkap sebuah cerita hingga makna yang dimaksud dapat tersampaikan.

Pembuatan narasi desain menggunakan gaya bahasa metafora berupa kalimat-kalimat ungkapan secara tidak langsung berupa perbandingan analogis berdasarkan persamaan dan perbandingan. Metafora digunakan untuk mengekspresikan ide desain sekaligus memperkaya pengalaman terhadap arsitektur melalui narasi desain. Narasi desain menjadi lebih banyak menggunakan aspek puitis dari sebuah ide. Pada narasi desain, atribut prostitusi digunakan sebagai perbandingan analogis terhadap desain [1].

\section{Domain to Domain Transfer}

Dalam mendesain sentra kuliner dan oleh-oleh, atribut terkait prostitusi digunakan dengan tujuan untuk memperkuat penggeseran makna pleasure menjadi enjoyment. Sebelum digunakan dalam eksplorasi desain, atribut prostitusi dikaitkan dengan elemen arsitektur dengan metode domain to domain transfer untuk mentranslasi domain dari luar arsitektur menjadi domain arsitektur. Kemudian hasil translasi ini digunakan untuk mengembangkan desain dengan menyesuaikan dengan narasi desain yang telah dibuat. Pada proses desain, narasi pengembangan desain dikembangkan secara berkesinambungan.

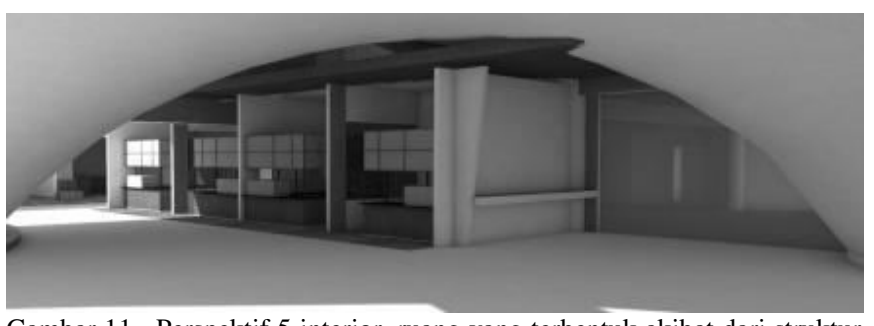

Gambar 11. Perspektif 5 interior, ruang yang terbentuk akibat dari struktur cangkang.

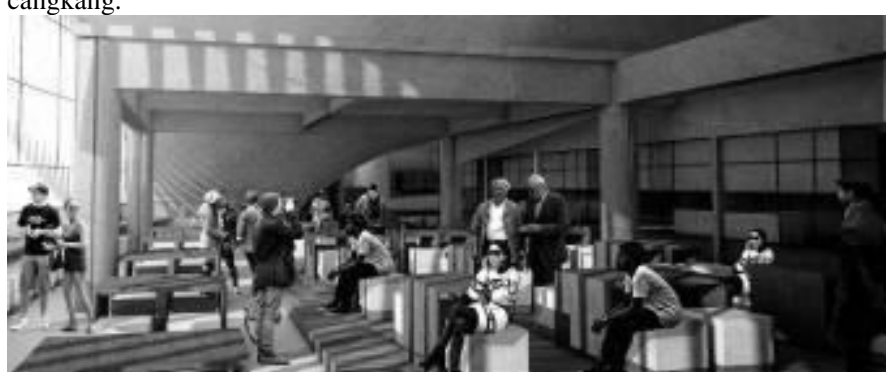

Gambar 12. Perspektif 6 interior, permainan bidang pada plat lantai.

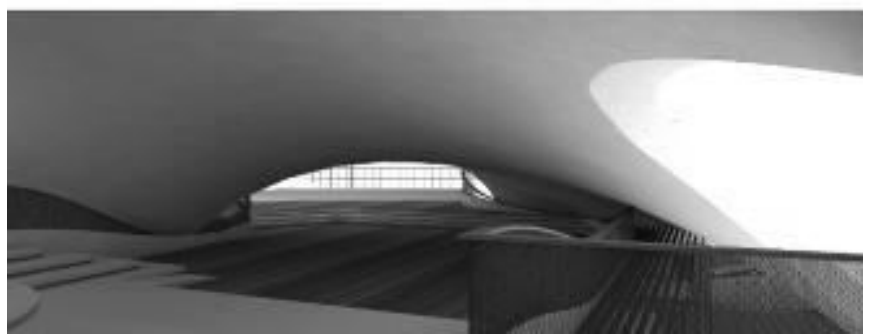

Gambar 13. Perspektif 7 interior, ruang yang terbentuk akibat dari struktur cangkang.

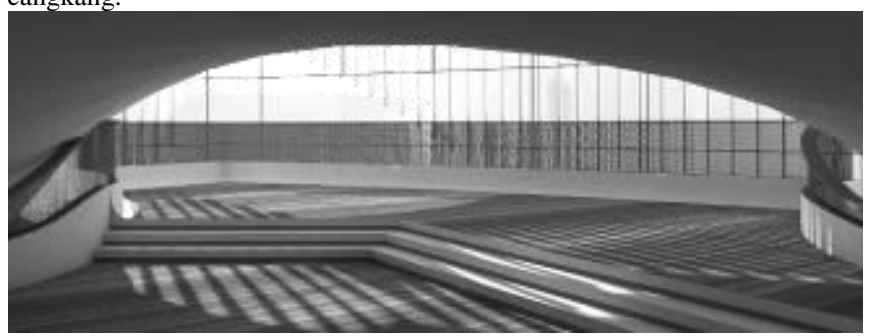

Gambar 14. Perspektif 8 interior, ruang tersembunyi yang ditutupi oleh struktur cangkang.

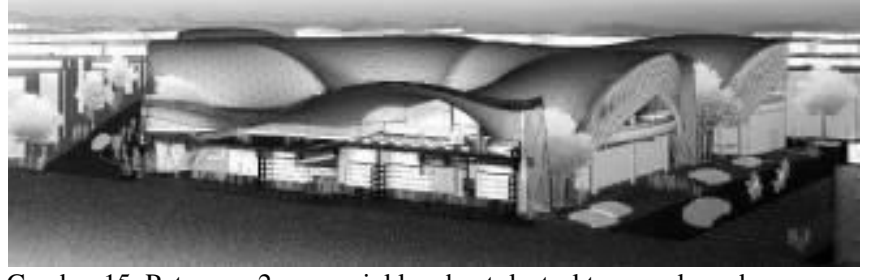

Gambar 15. Potongan 2, menunjukkan bentuk struktur cangkang bangunan.

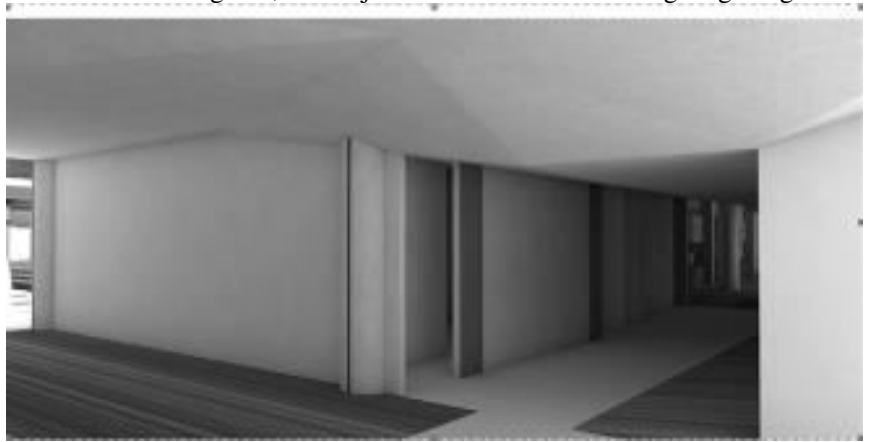

Gambar 16. Perspektif 9 interior, menunjukkan bentuk plafon 


\section{HASIL DESAIN}

\section{A. Konsep Desain}

Konsep desain merupakan fokus dari eksplorasi indra visual dan kinestetik, dan dikaitkan pada hasil domain transfer atribut prostitusi, yaitu permukaan dinamis (dynamic surface). Visual berkaitan dengan elemen warna, cahaya, bayangan, garis, pola, dan elemen lainnya. Kinestetik berkaitan dengan bentuk, material, dan tekstur. Transformasi desain dilakukan dengan cara mengolah sebuah permukaan, baik dengan ditekuk, disobek, atau ditekan. Selanjutnya, objek desain akan diceritakan melalui sebuah narasi desain, dengan diikuti rujukan gambar-gambar hasil desain terkait dengan narasi.

\section{B. Narasi Desain}

Bangunan seperti sebuah etalase kehidupan, aktivitas pengguna seakan menjadi sebuah objek yang dipertunjukkan melalui bingkai dengan bentuk permukaannya yang meliuk seperti ombak (Gambar 5).

Permainan bidang pada bingkai ini membuat beberapa bagian seakan dibuat menjadi lebih samar, sehingga menimbulkan rasa penasaran. Ketika menuju ke dalam, bangunan dengan bentuknya yang berlekuk terlihat seperti sebuah kain yang jatuh. Di bagian muka bangunan terlihat undakan yang dipadukan dengan permukaan yang miring. Setiap undakan terlihat seperti suatu bidang yang disobek lalu diangkat dan dilakukan secara terus menerus (Gambar 6).

Jalan itu mengarah ke atas, jalan ini juga diapit oleh dua pilar raksasa yang seakan muncul dari dalam tanah, menyerupai bentuk bunga yang akan mekar. Kedua pilar itu menimbulkan perasaan sempit dan gelap seperti memasuki suatu goa. Ruang yang terdapat dibalik dua pilar tersebut lebih megah dan tidak menyerupai goa. Lekukan kedua pilar itu berlanjut mengarahkan ke suatu titik yang berlubang (Gambar 7)

Dari lubang tersebut anak-anak dan pemuda berkegiatan disana. Orang-orang yang berkegiatan disana terlihat dikelilingi oleh dinding yang melengkung ke arah ke atas seperti sebuah bunga yang sudah mekar. Seperti bernaung dibawah bunga yang mekar, dinding yang mekar ini berhenti pada sudut-sudut bangunan dan membentuk menyerupai kelopak-kelopak bunga. Tempat-tempat orang berkegiatan seakan menjadi nektar yang berbentuk bulat (Gambar 8, 9, dan 10).

Kelopak bunga yang membentuk ruang-ruang dalam bangunan, memberikan kesan dinamis dengan materialnya yang halus. (Gambar 11).

Jalan pada bangunan ini pun tidak selalu rata, pada bagian tertentu memiliki tanjakan maupun bidang miring yang sekan terobek dan terangkat. Area yang terangkat seakan menjadi sebuah panggung. (Gambar 12).

Pada sisi lain bangunan terdapat suatu jalur dengan ketinggian ruang yang rendah, sehingga orang-orang harus duduk dibawah (lesehan) agar lebih nyaman untuk beraktivitas (Gambar 13).

Dari ujung lorong terlihat cahaya yang sebagian cahayanya menerangi lorong ini. Cahaya itu berasal dari ruang yang cukup megah yang bersembunyi di ujung lorong (Gambar 14,
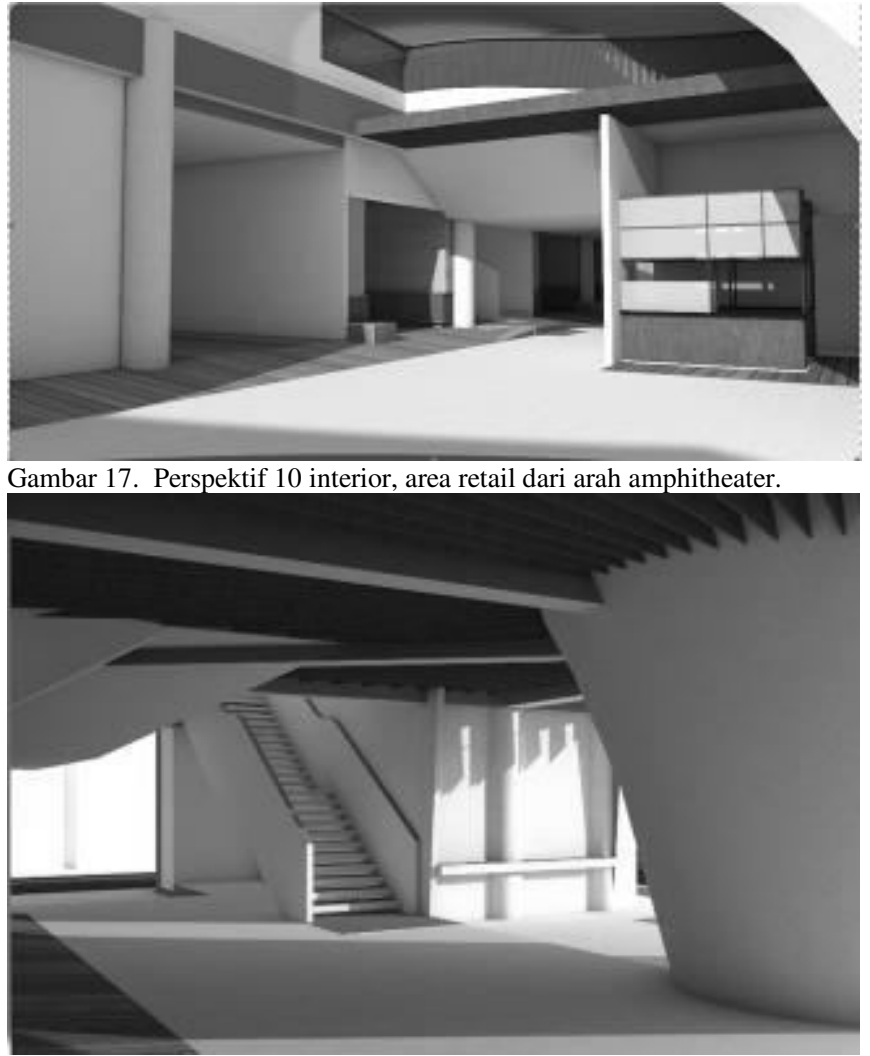

Gambar 18. Perspektif 11 interior, menunjukkan bentuk plafon yang terhubung dengan struktur cangkang.

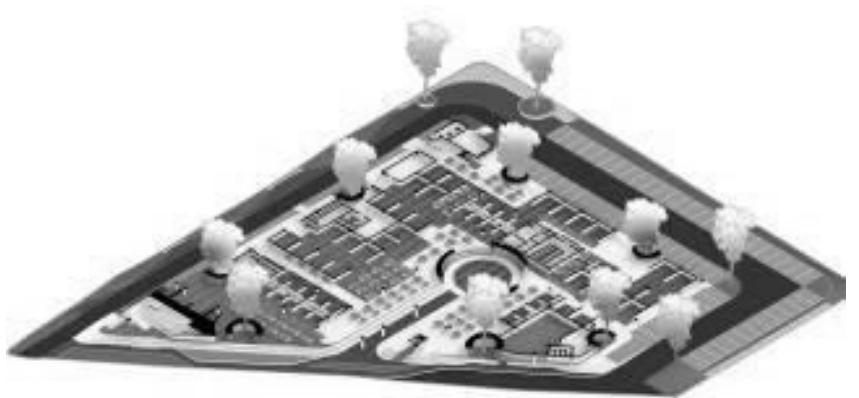

Gambar 19. Aksonometri lantai 1.

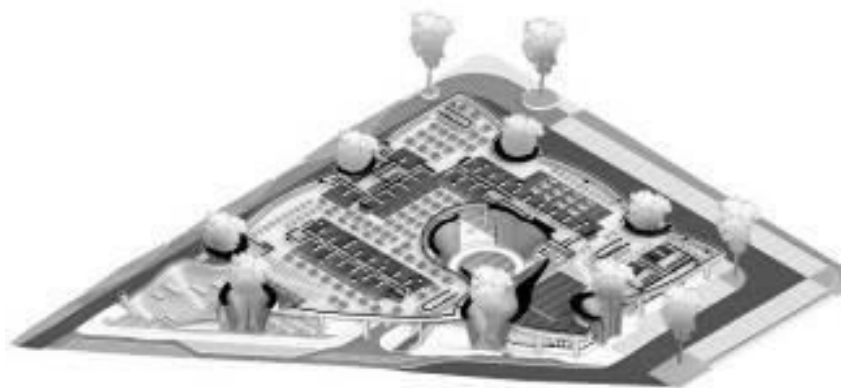

Gambar 20. Aksonometri lantai 2.

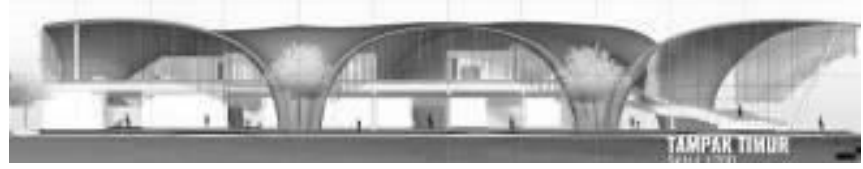

Gambar 21. Tampak timur bangunan, menunjukkan tampang bangunan. 
dan 15).

Pada area bawah bangunan ruang yang terbentuk cukup berbeda. Lorong-lorong bukan dibentuk oleh bidang yang elengkung, melainkan bidang yang dipatahkan dan semakin menyempit pada lorong yang diapit oleh etalase (Gambar 16).

Pada area etalase ruang lebih megah tanpa adanya kehadiran dari bidang-bidang yang ditekuk itu. Setiap kali menuju etalase harus melewati jalan miring dengan garis-garis lurus yang tepat mengarah ke dalam etalase tersebut (Gambar 17).

Di beberapa lorong hadir pilar bunga, dari bawah pilar tersebut terlihat seperti menembus dan melubangi suatu bidang. Pada bagian yang terlubangi terlihat bidang-bidang yang menjulur mengarah pada pilar dan menumpangi pilar bunga tersebut (Gambar 18).

\section{Transformasi Desain}

Penjelasan mengenai transformasi narasi desain menjadi objek desain akan dijelaskan dan diuraikan secara menyeluruh.

Pengolahan bentuk objek desain mengikuti bentuk tapak. Tapak diolah seperti sebuah kain yang diangkat, kemudian dijatuhkan, sehingga memiliki bentuk yang bergelombang pada bagian atasnya. Kemudian permukaan yang terbentuk ditekan pada titik tertentu untuk membentuk pilar penahan yang merupakan bagian dari struktur cangkang yang telah disesuaikan dengan kebutuhan pada desain. Tampang bangunan menjadi terlihat seperti ombak akibat dari lekukan yang terbentuk (Gambar 21, 22, 23, dan 24).

Masing-masing permukaan pada sisi bangunan pun diolah dengan cara pengolahan tapak. Kemudian, permukaan fasad dibuat dengan cara disobek dan dilubangi sedemikian rupa untuk menutupi atau mempertunjukkan bagian dalam bangunan. Fasad bangunan juga memiliki bentuk seperti ombak karena pola pada fasadnya dan lengkungan yang mengikuti bentuk dari bangunan. Bukaan pada fasad bangunan juga mempengaruhi permainan cahaya dan bayangan dalam bangunan, sekaligus mempertegas bentuk bagian dalam bangunan. Permainan cahaya dan bayangan akibat dari bentuk menjadi salah satu atraksi yang bisa dinikmati saat berada di dalam bangunan.

Permukaan plat lantai bangunan diolah dengan cara ditekan pada beberapa titik menyesuaikan dengan kebutuhan ruang dan kesan yang ingin dibentuk pada bagian dalam maupun luar bangunan. Kemudian bentuk dasar dari plat lantai yang terbentuk diolah dengan cara menyobek suatu permukaan kemudian diangkat, sehingga terbentuk area yang berundakundak sesuai dengan kebutuhan dari program ruang. Bentuk plat lantai seperti sebuah gelombang kecil yang mempengaruhi sensasi menjelajah dalam bangunan. Bagian permukaan yang terangkat diberi warna jingga untuk mempertegas (aksentuasi) perbedaan ketinggian dan sobekan pada permukaan. Warna jingga dipilih karena berdasar penelitian mengenai psikologi warna, jingga meningkatkan kesan enjoyment, fun, dan mempengaruhi selera makan.

Plat lantai yang terbentuk kemudian disesuaikan dengan kebutuhan penataan program ruang dan bentuk bangunan yang sudah dibentuk diolah dengan cara dilubangi dan disobek.

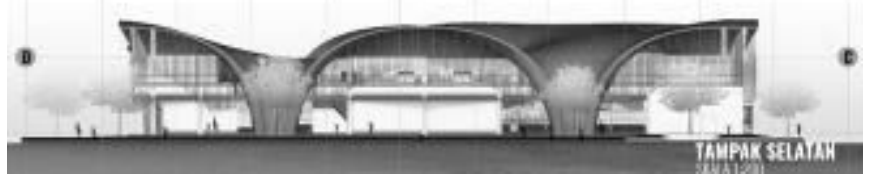

Gambar 22. Tampak selatan bangunan, menunjukkan tampang bangunan.

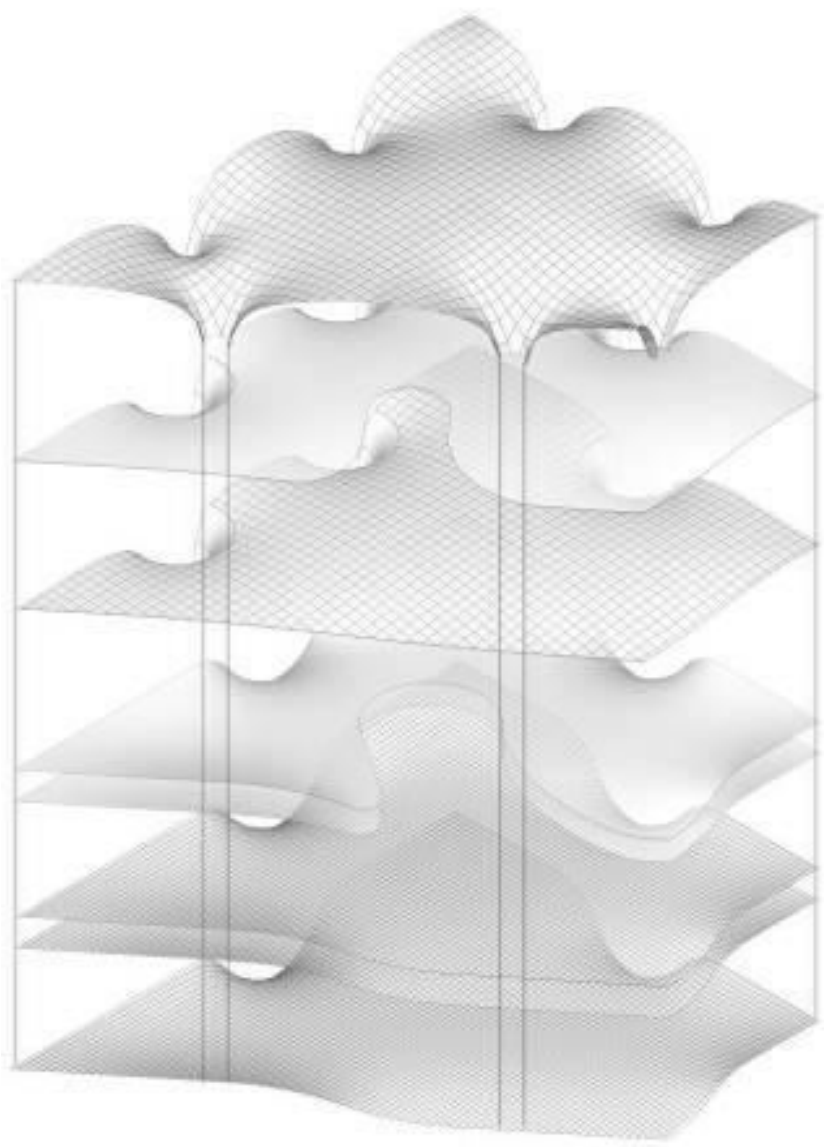

Gambar 24. Transformasi bentuk.

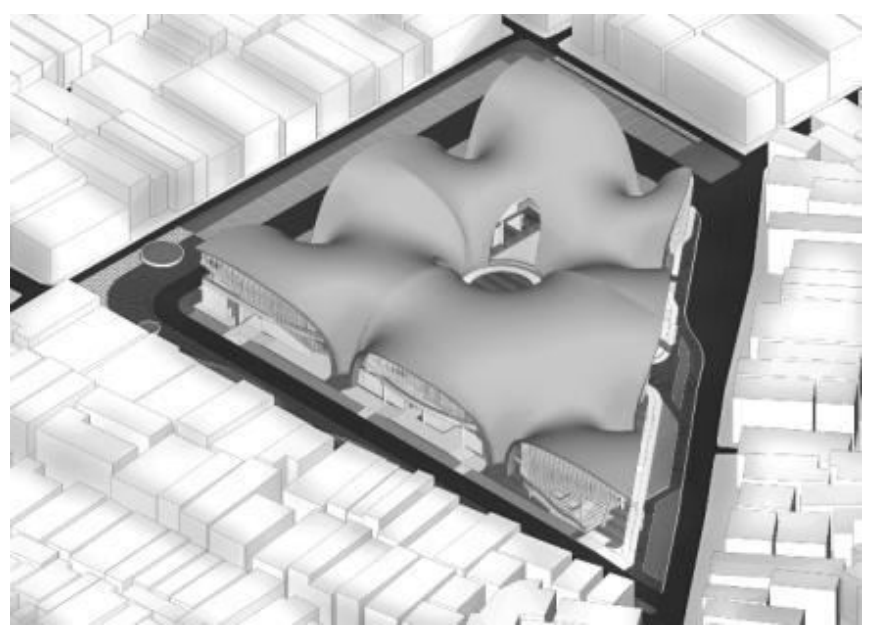

Gambar 25. Aksonometri, keberadaan objek desain terhadap lingkungan. 
Pengolahan plafon lantai 1 dilakukan dengan cara melipat dan menekuk permukaan dari plafon dengan ketinggian yang disesuaikan dengan fungsi ruang dan makna yang ingin ditunjukkan. Pertemuan pilar struktur cangkang dengan plat lantai 2 diolah dengan cara melubangi ditunjukkan dengan permainan dari kisi kayu yang mengelilingi pilar struktur cangkang (Gambar 18).

Variasi ruang yang terbentuk di dalam bangunan merupakan akibat dari penumpukan permukaan bangunan (struktur cangkang) dan plat lantai yang sudah diolah. Sehingga, dari dalam bangunan bentuk struktur cangkang menyerupai kelopak-kelopak bunga yang mekar. Variasi ruang memberikan kesan dan perasaan yang berbeda saat berkeliling di dalam bangunan. Material yang utamanya digunakan dalam desain adalah beton untuk memberikan kesan halus pada permukaan bangunan.

\section{KESIMPULAN}

Arsitektur merupakan salah satu cara untuk merubah citra suatu kawasan yang dulunya memiliki citra yang negatif menjadi citra yang positif. Menggeser atau mengganti citra lama kawasan menjadi citra yang baru dapat dilakukan dengan mempelajari citra lama dari kawasan tersebut. Kemudian, citra lama ini dikaitkan menjadi elemen arsitektur, sehingga citra lama digunakan untuk membuat citra baru namun dalam media yang berbeda. Mendesain suatu bangunan untuk memberikan citra baru perlu mempelajari lingkungan sekitar, baik itu secara fisik maupun non fisik (citra lama kawasan), sehingga citra baru tetap memiliki keterhubungan dengan kawasan itu. Citra yang ingin ditampilkan dalam objek belum tentu akan diinterpretasi sama oleh pengamat. Oleh karena itu, suatu karya arsitektur selain tetap berusaha untuk menonjolkan maknanya, juga harus tetap bisa diinterpretasi secara luas oleh pengguna bangunannya kelak.

Dalam mendesain dan menyampaikan makna yang terkandung dalam objek desain dapat menggunakan narasi desain yang kemudian akan ditransformasi menjadi objek desain itu sendiri. Pada proses desain sentra kuliner dan oleholeh ini, penulis memperkaya narasi desain menggunakan perbandingan dan analogi yang diambil dari atribut prostitusi. Kemudian, atribut prostitusi dikaitkan dengan eksplorasi indra visual, dan kinestetik, serta konsep permukaan dinamis untuk menimbulkan kedekatan (immediacy) pengguna dengan objek desain sehingga narasi bisa ditransformasi menjadi sebuah sentra kuliner dan oleh-oleh. Indra visual dan kinestetis distimulus oleh bentuk struktur dan atap yang bergelombang, serta bentuk plat lantai yang berundak-undak sehingga bisa menimbulkan makna enjoyment.

\section{UCAPAN TERIMA KASIH}

Penulis mengucapkan kepada Direktorat Pendidikan Tinggi, Departemen Pendidikan dan Kebudayaan Republik Indonesia yang telah memberikan dukungan finansial melalui Beasiswa Bidik Misi tahun 2014-2018. Penulis juga mengucapkan terimakasih kepada seluruh pihak yang telah membantu dan mendukung dalam penyelesaian jurnal ini.

\section{DAFTAR PUSTAKA}

[1] T. Porter, Archi Speak. London: Spon Press, 2004.

[2] G. Broadbent, Sign, Symbol, and Architecture. Los Angeles: The Pitman Press, 1980.

[3] N. Coates, Narrative Architecture. United Kingdom: John Wiley, 2012.

[4] H. Lefebvre, Toward an Architecture of Enjoyment. London: University of Minnesota Press, 2014. 